\title{
DEATH BECOMES HER: FEMALE SUICIDE IN FLAVIAN EPIC
}

\author{
Jessica Dietrich
}

\begin{abstract}
ecce inter medios caedum Tiburna furores
fulgenti dextram mucrone armata mariti

et laeua infelix ardentem lampada quassans

squalentemque erecta comam ac liuentia planctu

pectora nudatis ostendens saeua lacertis

ad tumulum Murri super ipsa cadauera fertur.
\end{abstract}

(Punica 2.665-70)

Look! Tiburna, into the middle of the raging of slaughter, having armed her right hand with the shining sword of her husband and, unhappy, shaking a burning torch with her left, filthy hair standing up and ferociously baring her arms to reveal breasts bruised from beating, she forces her way over the corpses themselves to the tomb of Murrus.

So Silius reintroduces the figure of Tiburna into the mass suicide at Saguntum in Punica 2 before concluding with a description of her suicide. ${ }^{1}$ The fury ${ }^{2}$ that surrounds Tiburna is not surprising of a female figure in Latin epic, yet her suicide in this context is perhaps at odds with the literary tradition in that it not the result of erotic passion but political despair. The suicide of female figures has a long literary tradition going back to Greek tragedy (Antigone, Deianira, Phaedra) as well as the Roman paradigms, Lucretia and Dido. In the epics of the Flavian period, Statius, Valerius Flaccus and Silius Italicus all offer up their own depiction of female characters who take their own lives. But unlike their literary sisters, whose suicides are an aspect of or the result of their gender, the Flavian epic heroines commit suicide despite their gender, a phenomenon that demands explanation. I will argue that these episodes in epic poetry owe more to the historical accounts of suicide in the Julio-Claudian era than to their epic predecessors. This connection may account for why these suicides seem overtly political in their direct opposition to tyranny. But the Flavian poets also seem reluctant to portray female suicide positively, and indeed their depiction of female suicide may be indicative of a larger cultural backlash in the Flavian period against the kinds of political suicides (and the growing contemporary corpus of literary hagiographies of prominent political suicides) so prominent in the first century $\mathrm{CE}$.

\section{Literary Models: Dido and Lucretia}

The influence of Virgil on the Flavian epicists is of course well recognised so it is worth considering the effect of his account of the suicide of the Car- 


\section{JESSICA DIETRICH}

thaginian queen, Dido, on the Flavian depictions of female suicide. Certain elements of Dido's suicide in Aeneid 4 are indeed present in the Flavian versions of female suicide. The magic ritual that Dido initiates in Aeneid 4, including the construction of a pyre, ${ }^{3}$ may be evoked in the necromancy performed by Aeson and Alcimede in Argonautica 1, in which the shade of Cretheus exhorts them to suicide. ${ }^{4}$ Both rituals are dedicated to the underworld deities ${ }^{5}$ and involve the presence of a priestess. ${ }^{6}$ Like Dido, Tiburna in Punica 2 builds a pyre with her husband's armour and falls upon a sword: sic ense recepto/arma super ruit ('and so with the sword having been taken in, she collapsed on to the weapons', Pun. 2.679f.). By using the sword of her husband, Tiburna's suicide is connected by Silius even more closely to that of Dido. ${ }^{7}$ Similarly, in the Thebaid, Jocasta uses the sword of Laius to end her life: regina ${ }^{8}$ extulerat notum penetralibus ensem,/ensem sceptriferi spolium lacrimabile Lai ("the queen had brought out the notorious sword from the inner chamber, that sword, the deplorable booty of sceptre bearing Laius', Theb. 11.635f.). But it is Argia in Thebaid 12 who casts herself as an abandoned wife, thus firmly establishing her connection to Dido: Argia asks herself heu quid ago? ('alas, what am I doing?', Theb. 12.328). Dido asks herself the same question, en, quid ago? ('ah, what am I doing?', Aen. 4.534) when she realises that Aeneas has left her. 'Despite these similarities and obvious references to Aeneid 4, however, the nature of Dido's suicide is significantly different from the Flavian representations of female suicide.

In the early empire, debate concerning Dido's suicide arose almost instantly; so Juvenal presents women discussing it at dinner parties: laudat Vergilium, periturae ignoscit Elissae ('she praises Virgil, excuses Dido about to die', Juv. Sat. 6.435). Recent discussions focus on the sexual nature of her suicide, ${ }^{10}$ as well as the political aspect," but perhaps the most persuasive arguments attempt to incorporate both explanations. Dido herself claims her death is deserved because she broke her oath to Sychaeus: quin morere ut merita es, ferroque auerte dolorem...non seruata fides cineri promissa Sychaeo ("why not die as you deserve and turn aside grief with the sword...faith was not kept which was promised to Sychaeus as ashes', Aen. $4.547,552$ ). Dido's relationship with Aeneas results in the loss of her pudor, which gives Dido her status in the Aeneid. Thus, Hill remarks, 'With the object of her desire lost, then, she has nothing at all, and it is for this reason, ultimately, that she kills herself., ${ }^{2}$ Dido's pudor, however, is the source of her claim on power over the Tyrians, and its loss is more than personal-it also represents the loss of this political authority. ${ }^{13}$ For Virgil's Dido there is a close connection between her sexual status as a woman and her public role as leader, which when severed, necessitates her suicide.

The death of a woman as the catalyst for political action is well established in the Latin tradition; the Lucretia of Livy and Ovid is the prime example. ${ }^{14}$ Like Dido, chastity is at the heart of Lucretia's story and her death is the result of the loss of pudor: 'Lucretia and Verginia would not be marked as victims to 
violence within Rome if they were not pure. ${ }^{15}$ Whereas Dido herself is a public figure, and thus readings of her death and character suggest a political interpretation, the essentially personal act of Lucretia in taking her own life is only made political by the immediate response of the male figures, in particular Brutus. Newlands suggests that Ovid's account of Lucretia's suicide in Fasti 2 goes even further in emphasising the gap between male and female behaviour: 'Ovid's Lucretia dies for personal reasons. But her silent passivity permits her death to be redescribed as a political act. ${ }^{16}$ Indeed, Brutus' revolutionary actions depend on the death of Lucretia; like Dido, Lucretia must die to fulfil the political ambitions of men. ${ }^{17}$ The narrative necessity of the deaths of Dido and Lucretia by suicide is predicated on their gender status as women, ${ }^{18}$ which seems entirely absent from the accounts in Flavian epic. ${ }^{19}$ Neither the lives nor the deaths of Argia, Alcimede and Tiburna are significantly marked by pudor and its lack or loss. Thus these female suicides seem to share less with their literary antecedents than at first glance might seem apparent, and it is worth exploring whether they owe more to contemporary accounts of suicide in the Roman world.

Grise's study of Roman suicide, especially her tabulation of historical suicides, illustrates the great number of political suicides from $14-69 \mathrm{CE}^{20}$ Griffin, in her pair of articles 'Philosophy, Cato and Roman Suicide' says that in this period, suicide was not just 'tolerated and accepted', but 'fashionable and esteemed', defining it as a kind of political martyrdom; ${ }^{21}$ two recent studies on Roman suicide, Hill's Ambitiosa Mors: Suicide and Self and Plass's Game of Death in Ancient Rome: Arena Sport and Political Suicide, also testify to the prevalence of aristocratic self sacrifice during the Julio-Claudian period. However, none of these studies of suicide in the Roman world distinguishes between male and female suicide. Despite including many examples of women who committed suicide, by identifying these as essentially political in nature these studies raise questions concerning female participation. ${ }^{22}$ They therefore overlook what is truly remarkable about the female examples: they reveal female political participation in the essentially patriarchal life of Rome.

Griffin suggests that the literary representation of such suicides may not be indicative of real suicides, concluding that 'what does arise from the celebration in literature of certain kinds of suicide is that the act, when performed in the right circumstances, was highly esteemed. ${ }^{23}$ McGuire's important work on suicide in the Flavian epics, ${ }^{24}$ however, suggests that suicide in the literary sources reflects an anxiety apparent in the historical sources as well. Thus a comparison of the suicides involving women in the Flavian epics with historical accounts may further a reading of suicide in the Roman world of the time. These literary depictions often serve to correct or contrast with the historical sources, particularly in terms of the outcome of the suicides, which in turn casts doubt on the nature of suicide itself. In order to facilitate the comparison of disparate sources, I have identified different kinds of historical female suicides 
that are also represented in the Flavian epics: (1) the suicide of an individual woman; (2) husband and wife joint suicide; (3) mass suicide including women.

\section{Individual suicide: Argia in Statius' Thebaid}

In Thebaid 12 Argia defies the edict of Creon, which threatened with death those who attempted burial of Argives, and acts essentially as an individual agent (although Antigone joins her on the battlefield). After the women have placed Polynices on the pyre, Statius describes the fervour with which they claim responsibility and seek death:

at ipsae
ante rogum saeuique palam spreuisse Creontis
imperia et furtum claro plangore fatentur
securae, quippe omne uident fluxisse cadauer.
ambitur saeua de morte animosaque leti
spes furit:...

deposcere saeua

supplicia et dextras iuuat insertare catenis....

et ad regem, qui deprendere, trahuntur.

(Thebaid 12.453-57, 459f., 463)

But the women themselves before the pyre openly admit that they have spurned the orders of hard Creon and confess the secret action with ringing wailing, careless since they see that the whole corpse has vanished. Harsh death is aimed at and an eager hope of death rages...it is pleasing to demand harsh punishment and to put right hands into chains...and those who captured the women are themselves dragged before the king.

This passage emphasises both Argia's and Antigone's deliberate pursuit of death; thus Argia's demonstrated willingness to die and deliberate violation of Creon's order that carried the death penalty may be considered a kind of suicide. But Statius breaks off his account of Argia and Antigone rushing towards their fate in order to narrate the Argive women's embassy to Athens. ${ }^{25}$ Thus Statius seems to leave the question of the fate of Argia open, although that of Antigone is, of course, well known from tragedy. Argia, however, appears briefly at the end of the epic among the other women lamenting ${ }^{26}$ indicating that she must have been spared, presumably by Theseus' intervention.

Argia's survival in itself might be surprising to Statius' audience familiar with the historical accounts of the suicides of individual women. In these accounts there is an element of 'overkill', that is, they are constructed both as suicide and execution. Agrippina, the wife of Germanicus, having been banished by Tiberius, abstains from food and thus kills herself: 
uoluntate extinctam, nisi si negatis alimentis adsimulatus est finis qui uideretur sponte sumptus.

(Tacitus Annals 6.25)

She died on purpose unless food was denied her so that her end was made to look like it was entered upon voluntarily.

By indicating the possibility of withheld food, Tacitus allows for the possibility that Agrippina's death was constructed as suicide in order to mask her execution. On the other hand, Suetonius suggests that Agrippina was denied suicide by Tiberius: rursus mori inedia destinanti per uim ore diducto infulciri cibum iussit ('again, when she was determined to die of starvation, he ordered her mouth to be pried open by force and food crammed in', Suet. Tib. 53). Both of these accounts suggest that Tiberius was deeply involved in Agrippina's suicide, if indeed he did not actually commit murder. ${ }^{27}$

Likewise, Messalina, when her execution is ordered, threatens suicide by holding a sword to her neck, but before she can deal her own fatal blow the tribune takes care of it for her: tunc primum fortunam suam introspexit ferrumque accepit, quod frustra ingulo aut pectori per trepidationem admouens ictu tribuni transigitur ("then for the first time she realised her fate and took the sword, but because of her terror she pressed it to her neck and breast in vain, and was run through by the tribune', Tac. Ann. 11.38). There may be a parallel with another female suicide in the Thebaid here-Jocasta in Book 11.

Although Statius makes it clear that Jocasta is successful in killing herself, perhaps in contrast with Oedipus who is prevented by Antigone, he emphasises the difficulty Jocasta experiences in fatally wounding herself: et prono uix pectore ferrum/intrauit tandem ('and scarcely at last did the sword go through her stooped breast', Theb. 11.639f.). Through the difficulty in achieving her own death in the Thebaid, Jocasta conforms to certain aspects of female suicide in the historical sources and thus marks a significant contrast with the presentation of Argia in Thebaid 12.

In these cases of individual female suicide by historical figures, there is considerable ambiguity regarding the nature of their suicides, and these are indeed constructed as murder or execution. Perhaps there is a sense that a woman might not be capable of taking her own life and that individual suicide is a male prerogative. To phrase it another way, individual suicide requires a certain manliness that not even all men possess. Tacitus mentions Caninius Rebilus who

...cruciatus aegrae senectae misso per uenas sanguine effugit, haud creditus sufficere ad constantiam sumendae mortis ob libidines muliebriter infamis.

(Tacitus Annals 13.30) 


\section{JESSICA DIETRICH}

...escaped the miseries of an old age of broken health by letting the blood trickle from his veins, though men did not credit him with sufficient resolution for a self-inflicted death because of his infamous effeminacy. ${ }^{28}$

As Caninius Rebilus must overcome effeminacy to commit suicide, Statius makes a similar claim for Argia in Thebaid 12 when she embarks on her suicide mission. Having heard the report of Creon's edict, which she is determined to violate, Argia has an extraordinary metamorphosis in which she seems to become a man:

hic non femineae subitum uirtutis amorem colligit Argia, sexuque inmane relicto tractat opus.

(Thebaid 12.177-79)

Here Argia contracts a sudden passion for unfeminine manliness and undertakes a huge task, having left behind her gender.

In creating a masculine Argia, or a woman who displays a new kind of feminine uirtus or manliness, Statius removes the paradoxical aspects of the historical accounts of Agrippina and Messalina and thus allows Argia to devote herself to suicide. But in the inverted world of the Thebaid, every silver lining has its dark cloud, and it is perhaps worth pausing to consider the effect of Argia's elevation to male status and the efficacy of her action.

When Argia has her metamorphosis into this kind of manly figure, she resolves to separate herself from the Argive women: tunc mouet arte dolum ('she devised a trick with skill', Theb. 12.183). Telling the Argive women to go to Athens to petition Theseus for help, Argia does not tell them her plans to bury Polynices against the edict of Creon, and it is not clear whether she is trying to protect them or to take the glory for herself. Tacitus, for one, saw the latter motive as at least problematic: in his Agricola, the biography of his father-in-law and a polemical response to Stoic martyrdom and contemporary hagiographical accounts of them, he sets the glorification of individual martyrs against service to the Roman state:

sciant, quibus moris est inlicita mirari, posse etiam sub malis principibus magnos uiros esse, obsequiumque ac modestiam, si industria ac uigor adsint, eo laudis excedere, quo plerique per abrupta, sed in nullum rei publicae usum ambitiosa morte inclaruerunt.

(Tacitus Agricola 42)

Let those for whom it is a habit to admire illegal things know that even under bad emperors men are able to be great, and that compliance and 
propriety, if diligence and force are also present, can go beyond to that place of praise where many men become famous via a precipitous path by an ostentatious death but with no benefit to the state. ${ }^{29}$

So, perhaps, Argia's attempted suicide may be meant to be read negatively - a futile waste of a potentially useful life. Also relevant here may be the death of Maeon in Thebaid 3.30. Maeon, as the sole survivor of Tydeus' defence against the Theban ambush, reports back to Eteocles, condemning his tyranny, drawing his sword and stabbing himself. McGuire suggests that Statius, while viewing suicide as the ultimate resistance to tyranny, doesn't present suicide as achieving much of anything: so Maeon would have been better off killing Eteocles rather than himself. ${ }^{31}$

Argia achieves a certain status in the final book of the Thebaid and we may be meant to view her as a kind of heroic figure. Yet by deliberately seeking death in defying the tyranny of Creon, the figure of Argia may also serve to remind Statius' Roman audience of those imperial women, such as Agrippina and Messalina, whose deaths are constructed more as an expression of the power of the emperor, rather than of the opposition to his power.

\section{Husband and wife joint suicide: Alcimede with Aeson in Valerius Flaccus' Argonautica}

Whereas Argia's attempt to kill herself is unfulfilled and perhaps indicates the futility of her actions, Valerius Flaccus treats Alcimede's success in accompanying her husband in death as similarly problematic. Following the necromancy to consult with the shade of Aeson's father, the couple is warned of Pelias' treachery and urged to seek death. Aeson resolves on suicide and Alcimede expresses her desire to join him in his fate. Thus they both drink the bull's blood $^{32}$ and are found in their death throes, as Pelias' men burst in:

in media iam morte senes suffectaque leto lumina et undanti reuomentes ueste cruorem conspiciunt.

(Argonautica 1.821-23)

They catch sight of the old ones in the middle of dying, their eyes suffused with death, vomiting blood on damp clothes.

The connections with historical examples of suicide are well established, although scholarly opinion is divided as to the efficacy or worth of such acts. Zissos, in his recent commentary on Book 1, argues that Aeson is presented positively, affirming the moral value of suicide, ${ }^{33}$ while McGuire senses a dis- 


\section{JESSICA DIETRICH}

quieting note in the presence of the fury. ${ }^{34}$ Neither, however, comments on Alcimede or her participation in the suicide. ${ }^{35}$

Taylor, however, sees a close connection between Alcimede and Arria Minor, who, in Tacitus' account, demonstrates a similar desire to die with her husband, the Stoic martyr Thrasea Paetus. ${ }^{36}$ It is worth a closer look the specific parallels; unfortunately, the account of the suicide of Thrasea Paetus breaks off before Tacitus can tell us the fate of his wife, but he connects Arria Minor's desire for suicide to that of her mother, Arria Maior, who is perhaps the most famous Roman historical example of female suicide: Arriamque temptantem mariti suprema et exemplum Arriae matris sequi ("Arria trying to follow the death of her husband and the example of her mother Arria', Tac. Ann. 16.34). Pliny records the events surrounding Arria Maior's suicide remarking that, as she stabbed herself to encourage (or shame) her husband, Caecina Paetus, she declares to her husband 'Paete, non dolet' ('Paetus, it doesn't hurt', Plin. Ep. 3.16). ${ }^{37}$

Unlike her mother, it seems likely that Arria Minor did not join her husband in suicide, but rather was persuaded by his exhortation to live for the sake of their daughter-monet retinere uitam filiaeque communi subsidium unicum non adimere ('he warns her to hold on to her life and not to take away the sole support of their daughter', Tac. Ann. 16.34). Pliny's letter on the illness of Fannia, Arria's daughter, indicates that Arria did indeed live to her daughter's maturity and may have been instrumental in Fannia's development into a woman of considerable influence. Of Arria here, Pliny says me quidem illud etiam affligit et torquet, quod matrem eius, illam-nihil possum illustrius dicere-tantae feminae matrem, rursus uideor amittere ('indeed this also distresses and torments me, that I seem again to be losing her [Fannia's] mother, that mother-I am able to say nothing more distinguished-of so great a woman', Pliny Ep. 7.19). Through remaining alive and by not following Thrasea Paetus in his suicide Arria is able to raise a daughter such as Fannia who embodies the values of her parents, preserving them into the next generation. In fact, none of the historical examples, or indeed literary examples before Valerius Flaccus, of Roman wives who express a desire to join their husbands in suicide results in their immediate death.

In addition to Arria, Paulina, the wife of Seneca, planned to die with her husband, but may have been prevented by Nero. ${ }^{38}$ But Tacitus also casts doubt on Paulina's motivation to live, indicating a baser desire: with Nero's hostility removed (presumably at the death of Seneca), Paulina was 'overcome by the allure of living' (euictam blandimentis uitae, Tac. Ann. 15.64). Whatever the reason, it is clear that Paulina, despite expressing her willingness to die with Seneca, did not actually follow through. Another example is Munatia Plancina, wife of Calpurnius Piso, who was condemned to death with her husband for their role in the death of Germanicus, but was spared suicide by the intervention of Livia. ${ }^{39}$ In the realm of epic poetry, in Lucan's Bellum Civile, Cornelia expresses her responsibility for Pompey's situation as well as a desire to die 
with her husband, ${ }^{40}$ but finally claims that she is prevented from suicide in order to be captured by Caesar: prohibent accersere mortem, $/$ seruor uictori ('they forbid me to summon death; I am saved for the victor', Lucan $B C$ 8.660f.). Like Paulina, who may have been spared by the emperor, and Plancina, who was spared by Livia, Cornelia is kept alive after her husband by the will of Caesar.

Returning to Alcimede's suicide in the Argonautica, it might also be worth pointing out that in his exhortation to suicide the ghost of Cretheus addresses himself to Aeson alone, using a singular pronoun and verbs:

quin rapis hanc animam et tremulos citus effugis artus $i$, meus es, iam te in lucos pia turba silentum secretisque ciet uolitans pater Aeolus aruis.

(Argonautica 1.749-51)

Why not snatch away this life and quickly flee these trembling limbs? Come, you are my son, already the holy crowd of the silent and my father Aeolus, who flits in the secret fields, hurry you into their groves.

Cretheus does not seem to expect Alcimede to follow her husband's example ${ }^{41}$-nor might Valerius' readers. Like Arria, Alcimede has children, and while she has been assured of Jason's safety by Cretheus' shade, ${ }^{42}$ Valerius places Aeson and Alcimede's younger son, Promachus, at the centre of their suicide. As McGuire points out, the death of Promachus at the hands of Pelias' men immediately after the death of his parents undermines Aeson's wish that the boy should benefit from his father's example. ${ }^{43}$ McGuire concludes that Valerius 'undercuts the reader's impulse to endorse absolutely the actions of Jason's parents'. ${ }^{44}$ I would add to this that Alcimede's expressed willingness to die with Aeson is consistent with what we read in the historical sources, but her actual death is unexpected and, unlike Arria, who lives for the sake of her daughter, Alcimede's suicide exposes her young son to further violence and negates any positive outcome of her suicide.

Husband and wife joint suicide is particularly Roman and Valerius constructs Alcimede as a proper Roman matrona by depicting her following her husband in death. The historical examples include women who seem to support the political opposition of their husbands, figures such as Seneca and Thrasea Paetus, but, by surviving, these women instead become instances of the clemency of the emperor. In her pursuit of death, then, Alcimede remains a potent symbol of the opposition to Pelias' tyranny, but in her wifely devotion, she fails as a mother. This disorder in family relationships may actually do more to support the power of the tyrant rather than disrupt it. Whereas Arria survives to raise her politically influential daughter, Promachus' death means that Aeson's and Alcimede's values will die with them. 


\section{JESSICA DIETRICH}

\section{Mass suicide: Tiburna at Saguntum in Silius' Punica}

Tiburna participates in the mass suicide at Saguntum described by Silius in Punica 2. She appears-ecce-amidst the slaughter, brandishing a sword and a torch. She then lights a pyre of her husband's weapons (Murrus, killed by Hannibal in Book 1) and stabs herself with his sword:

arma uiri multo nuper defensa cruore imponit tumulo inlacrimans, manesque precata acciperent sese, flagrantem lampada subdit. tunc rapiens letum 'tibi ego haec' ait 'optime coniux, ad manes, en, ipsa fero.' sic ense recepto arma super ruit et flammas inuadit hiatu.

(Punica 2.675-80)

Weeping she places the arms of her husband recently defended with much blood on the pyre and having prayed that the shades receive her, puts her flaming torch under. Then snatching at death she says 'I myself bear these things for you, best husband, to the shades.' So, taking the sword, she falls down upon the arms and drinks in the fire with gaping mouth.

Her action is swift and decisive, the culmination of the violence and despair that precedes it, namely the mass suicide of the Saguntines in the face of Hannibal's attack. In constructing the events at Saguntum as mass suicide, Silius breaks from his historical sources, Livy and Polybius, who both describe a long siege at Saguntum, but differ as to the ultimate fate of its inhabitants; Livy suggests that some of the Saguntines threw themselves on the fire and the surviving adult males were killed by the order of Hannibal, ${ }^{45}$ while Polybius indicates that Hannibal enslaved everyone. ${ }^{46}$ McGuire argues instead that Silius' description of the suicide evokes images of civil war, most specifically from Lucan's Bellum Civile. ${ }^{47}$ The descriptions of civil war in Lucan's epic include slaves killing masters, sons killing fathers, brothers killing brothers, ${ }^{48}$ but in the Punica, the participants include women-sons kill mothers: hic, turbidus iralet rabie cladum perpessaeque ultima uitae,/obliquos uersat materna per ubera uisus ("this one, disturbed by anger and rage of slaughter and life endured, turns his averted glance at his mother's breast', Pun. 2.619-21); and husbands kill wives: hic, raptam librans dilectae in colla securim/coniugis, increpitat sese mediumque furorem/proiecta damnat stupefactus membra bipenni ('this one, levelling a snatched up axe at the neck of his beloved wife, rebukes himself and condemns his uncompleted frenzy, as, limbs paralysed, he drops his weapon down', Pun. 2.622-24). An easier reading is available: the role of women and Tiburna's suicide in particular in the Saguntum episode is perhaps not only an aspect of civil war, but may also in fact, as we would expect, be related to his- 
torical accounts of nations or cities under siege. One example is Plutarch's description of the Germans after their defeat by Marius, which indicates that women actively took part in the suicide:

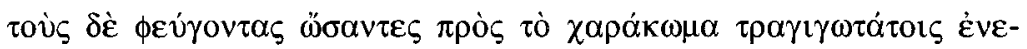

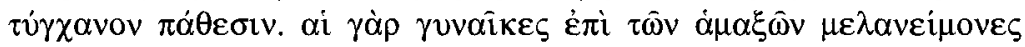

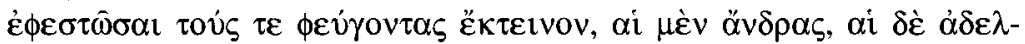

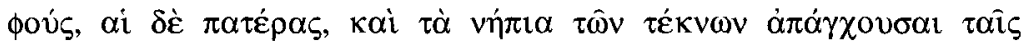

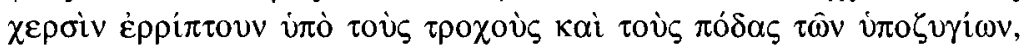

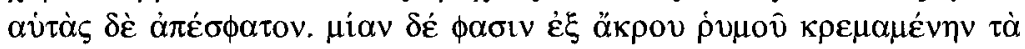

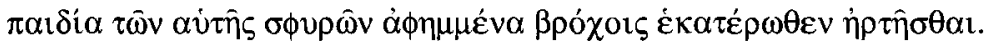

(Plutarch Gaius Marius 27.2-3)

After driving the fugitives back to their entrenchments, they [the Romans] beheld a most tragic spectacle. The women, in black garments, stood at the wagons and slew the fugitives-some their husbands, some their brothers, some their fathers - then with their own hands strangled their little children and threw them beneath the wheels of the wagons or the feet of the cattle, and then cut their own throats. It is said that one woman hung dangling from the tip of a wagon-pole, with her children tied to either ankle.

(after Perrin) $)^{49}$

Plutarch's German women are not only among those slaughtered, but actively take part by killing their children as well as themselves.

Perhaps the most famous account of mass suicide (and relevant here, as it is a Flavian source) is Josephus' account of the events at Masada. Josephus describes the men embracing their wives and children before killing them. Women are also given an important role at the end of the episode-not those who died, but two who survive:

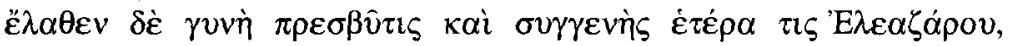

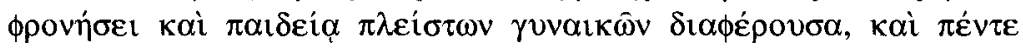

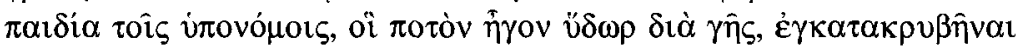

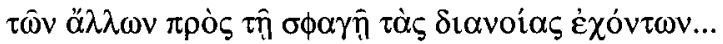

(Josephus, Jewish War 7.399)

But an old woman and another, a relative of Eleazar, superior in sagacity and training to most of her sex, with five children, escaped by concealing themselves in the subterranean aqueducts, while the rest were absorbed in the slaughter.

$(\text { tr. Thackeray })^{50}$ 


\section{JESSICA DIETRICH}

These two women survive in order to bear witness of the actions at Masada to the approaching Roman army. In these accounts of mass suicide not only are women marked out as important participants, but these suicides are performed by non-Romans in the face of Roman aggression, and the value of the action is in the resistance to Rome.

Dominik has demonstrated that the Saguntine episode is programmatic for the role of Rome in the Punica suggesting that Rome is 'in a sense responsible for the destruction of Saguntum'. events at Saguntum in Punica 2 are mirrored in Book 13's description of the Roman siege of Capua, which had sided with Hannibal. One of the episodes in Book 13 is of the suicide of Taurea. Silius indicates this is a noble deed, even if performed by an enemy: hic atrox uirtus (nec enim occuluisse probarim/spectatum uel in hoste decus) ('this dreadful act of courage - for I would not approve to keep hidden an esteemed honour even in an enemy-', Punica 13.369f.). Perhaps then Tiburna's suicide in Book 2 might also be considered an esteemed deed, even if performed by a woman. Roman aggression or betrayal generates such noble and indeed virtuous, if violent reactions.

Tiburna's suicide, however, is not her first appearance in Punica 2 and it is her earlier manifestation that may undermine any positive assessment of her death. ${ }^{52}$ The mass slaughter at Saguntum is initiated by the divine intervention of Juno who sends the fury Tisiphone to the city. In order to whip the crowd into a frenzy, Tisiphone assumes the likeness of Tiburna in a scene that has many close parallels with Iris' intervention in Aeneid $5 .^{53}$ In the Aeneid Iris/Beroe claims that Cassandra appeared to her in a dream to encourage the Trojan women to alleviate their toil by refusing to continue the journey and insisting on making their home in Sicily. ${ }^{54}$ Silius evokes Iris/Beroe's speech when Tisiphone/Tiburna also claims that a vision appeared to her in a dream to warn the Saguntines. In the Punica, it is Tiburna's dead husband Murrus who tells her that Saguntum is lost to the Carthaginians. Tisiphone/Tiburna suggests a rather more violent solution than Iris/Beroe by telling the young men of the city to kill the women in order to save them from slavery. ${ }^{55}$ At the end of Iris/Beroe's speech, she snatches up the firebrand to set the Trojan ships on fire-an act which stuns the Trojan women. But in Silius a snake appears whose bloody eyes seem to radiate flames, ${ }^{56}$ an image that may be a reference to the flames of the fire caused by the women at the end of Aeneid 5 .

In Aeneid 5, the burning of the ships by the women almost destroys the Trojan fleet, nearly preventing the continuation of Aeneas' undertaking. In Punica 2 , the Saguntines build a huge pyre and then, inspired by the fury, launch into mass suicide and mutual slaughter. In evoking Aeneid 5, Silius alludes to Virgil's presentation of frenzied female behaviour, but although Virgil subverts this voice through divine intervention, Silius gives full play to this destructive element. Aeneid 5 ends with the intervention of Jupiter, whose rainstorm spares four ships and leads to the compromise to leave a community of Trojans behind in Sicily, but the episode in Punica 2 concludes with the suicide of Tiburna. 
The historical sources may indicate a positive reading of Tiburna's suicide as opposition to Roman aggression, like the Germans against Marius or the Jews at Masada. Even Silius himself indicates the nobility of such an action through the figure of Taurea at Capua in Punica 13. But through the juxtaposition of Tiburna's death with the intervention of Tisiphone in the guise of Tiburna in Punica 2, Silius emphasises the madness and frenzy behind the mass suicide in general and, perhaps, specifically of Tiburna herself. As with the suicides of Argia and Alcimede, the reader is left questioning the value or efficacy of such an action.

\section{Conclusion: Female Suicide in context}

In 2005 Jordanian police arrested Sajida Mubarak al-Rishawi in connection with a bombing at a hotel in Amman. Her husband had been killed when he detonated a bomb killing 57, but she claimed hers had 'failed to go off' and so she fled the scene at her husband's order. ${ }^{57}$ At the time, much was made of her gender - female suicide bombers were fairly rare. One expert suggested that 'the longer a suicide terrorist campaign tends to go on...the more likely groups are to have women suicide terrorists'. ${ }^{58}$ Indeed this trend may have been anticipated by a 2004 report for the Strategic Studies Institute that also indicated a new willingness to use women, despite the anxiety expressed by Sheikh Ahmed Yassin, spiritual leader of Hamas, who said 'Hamas was far from enthusiastic about the inclusion of women in warfare, for reasons of modesty' ${ }^{59}$ Organisations such as Hamas that use suicide bombing construct these suicides as a kind of martyrdom, which should generally exclude women because these groups are representative of cultures in which women are not afforded political or religious agency. But two years later, since women could more easily reach targets, Yassin claimed 'women are like the reserve army - when there is a necessity, we use them' ${ }^{60}$

In modern analysis of suicide bombings, female participation can only be constructed as positive by those who conduct it in response to extreme aggression, of which groups like Hamas see the US superpower and the dominant West in general as guilty. Female suicide in Flavian epic is also a response to tyrannical oppression: Alcimede joins Aeson in resisting Pelias, Argia violates Creon's edict and Tiburna with the Saguntines, having been betrayed by Rome, faces Hannibal's might. But are they necessary? Aeson's suicide would have been enough to challenge Pelias, whereas Theseus is the only one who can stop Creon. Alcimede in the Argonautica, as a Roman matrona who desires to follow her husband in death, violates her responsibility to her own son. In the Thebaid, Argia casts aside a feminine nature to embark upon on a masculine quest to oppose tyranny, but her actions achieve nothing - not even her own death. Tiburna in Punica 2 perhaps does represent a kind of virtuous female suicide and perhaps the nature of her gender makes her a more potent symbol. 


\section{JESSICA DIETRICH}

In the 2004 report on female suicide bombers, the use of women is cited by experts on the Middle East 'to show that things are so desperate that women are fighting instead of men' ${ }^{61}$ That may be the case for all three of Flavian epicseach deals with desperate situations, but each offers its own reading as to whether or not the war is worth fighting, and especially dying, for.

\section{Australian National University}

\section{NOTES}

1. This paper was first delivered at the Pacific Rim Roman Literature Seminar at University College London, July 2009. I would like to thank the participants of the seminar for the lively discussion and feedback as well as additional comments by Peter Davis and A.J. Boyle. The title was suggested by Robin Bond.

2. See François Spaltenstein, Commentaire des Punica de Silius Italicus (livres 1 à 8 ) (Genève 1986), 172f., for the connections between Tiburna and the furies.

3. Aen. 4.474-521.

4. Cf. Andrew Zissos, Valerius Flaccus' Argonautica Book $/$ (Oxford 2008), xxxv: 'Thay [Aeson and Alcimedel perform rites to facilitate the suicide, corresponding to Dido's magical rites.' See Timothy D. Hill, Ambitiosa Mors: Suicide and Self in Roman Thought and Literature (New York 2004), 118, for identifying Dido's ritual as a necromancy.

5. Alcimede brings offerings to Tartarean Jupiter and the Stygian shades (Tartareo tum sacra loui Stygiisque...manibus, Arg. 1.730f.) just as Dido completes the rites to Stygian Jove (sacra Ioui Stygio, Aen. 4.638) before her suicide.

6. sacerdos at Arg. 1.755 and Aen. 4.483, but she is Massylian in the Aeneid (gentis Massylae, Aen. 4.483) and Thessalian at Arg. 1.737 and 780. The Thessalian priestess is often identified as Alcimede herself. Cf. Zissos (n.4 above), 384, and A.J. Kleywegt, Valerius Flaccus Argonautica Book 1: A Commentary (Leiden 2005), 429. For a full discussion of the ritual see Sylvie Franchet D'Espèrey, 'Une étrange descente aux enfers: le suicide d'Éson et Alcimédé (Valerius Flaccus, Arg. I 730-851)', in D. Porte and J.-P. Neraudau (eds.), Hommages a Henri Le Bonniec: Res Carae (Brussels 1988), 193-97.

7. Cf. Aen. 4.663-65. If this weren't obvious enough, the words arma uiri which introduce Tiburna's suicide must be an explicit reference to the opening line of the Aeneid.

8. Statius' use of regina would also evoke Dido in Aeneid 4.

9. See Jessica Dietrich, 'Rewriting Dido: Flavian Response to Aeneid 4', Prudentia 36 (2004), 1-30, for full discussion of Argia as a Dido figure in the Thebaid.

10. See Daniel Gillis, 'A Marriage at Carthage', in Eros and Death in the Aeneid (Rome 1983), 37-52, and A.M. Keith, Engendering Rome: Women in Latin Epic (Cambridge 2000), 115, for the erotic nature of Dido's death.

11. See Richard Monti, The Dido Episode and the Aeneid: Roman Social and Political Values in the Epic (Leiden 1981) for a political interpretation of the Dido episode.

12. Hill (n.4 above), 111.

13. Cf. Hill (n.4 above), 113: 'Dido's social standing and her fidelity to Sychaeus should be viewed as inextricably bound to each other, so that it is impossible for her to assert her place amongst the Tyrians without proving also her faithfulness to her husband.'

14. Cf. Keith (n.10 above), 130: 'The death of a beautiful woman repeatedly serves as the catalyst in Latin epic for the epic hero's assertion of political agency.' For full discussion see her chapter 'Over her Dead Body', but Keith does not distinguish suicide from other types of violent death.

15. P.K. Joplin, 'Ritual Work on Human Flesh: Livy's Lucretia and the Rape of the Body Politic', Helios 17 (1990), 56.

16. Carole Newlands, Playing with Time: Ovid and the Fasti (Ithaca 1995), 153.

17. Cf. Sandra Joshel, 'The Body Female and the Body Politic: Livy's Lucretia and Verginia', in A. Richlin (ed.), Pornography and Representation in Greece and Rome (Oxford 1991), 112-30, at 119, who defines Livy's heroes as 'men who act when women are made dead'. 


\section{FEMALE SUICIDE IN FLAVIAN EPIC}

18. Keith (n.10 above), 104: 'Female death is pervasively sexualized in Latin epic.'

19. Keith ( $n .10$ above) does not include any of the suicides of women in the Flavian epics, treating only Valerius' account of the death of Helle in any detail.

20. Yolanda Grise, Le suicide dans la Rome antique (Paris 1982). Of the 19 pages accounting for suicides from the monarchy through to the reign of Commodus, seven are devoted to this period of 55 years (this may simply reflect the better documentation for this period, especially via Tacitus).

21. Miriam Griffin, 'Philosophy, Cato and Roman Suicide: I', $G \& R 33$ (1986), 69f.

22. Hill (n.4 above), 28, acknowledges the limited attention to female practitioners of suicide.

23. Miriam Griffin, 'Philosophy, Cato and Roman Suicide: II', G\&R 33 (1986), 200.

24. See both the article 'Textual Strategies and Political Suicide in Flavian Epic', in A.J. Boyle (ed.), The Imperial Muse: Flavian Epicist to Claudian (Bendigo 1990), 21-45, as well as his monograph Acts of Silence: Civil War, Tyranny, and Suicide in the Flavian Epics (Hildesheim 1997).

25. at procul ('but far away...' Theb. 12.464)

26. ut saeuos narret uigiles Argia sorori ('Argia tells her sister how cruel the watchmen were', Theb. 12.804).

27. Tiberius' attempts to take credit for not killing her are also cited by both historians.

28. Nero might be another example here who, as Suetonius records, needed the help of his freedman to deal the death blow (Nero 49).

29. For a discussion of this passage see John L. Penwill, 'Expelling the Mind: Politics and Philosophy in Flavian Rome', in A.J. Boyle and W.J. Dominik (eds.), Flavian Rome: Culture, Image, Text (Leiden \& Boston 2003), 345-68, at 361f.

30. See McGuire's discussion of Maeon (n.24 above 'Textual Strategies', 28-33). He does not, however, consider Argia's suicide.

31. McGuire (n.24 above 'Textual Strategies'), 32.

32. illi auide exceptum pateris hausere cruorem ('they eagerly drain the blood received from the sacrificial dish', Arg. 1.818).

33. Zissos (n.4 above), 412 .

34. adstitit et nigro fumantia pocula tabo/contigit ipsa graui Furiarum maxima dextra ('the greatest of the Furies stood nearby and touched the cup foaming with black poison with her weighty right hand', Arg. 1.816f.). McGuire (n.24 above "Textual Strategies'), $26 \mathrm{f}$.

35. Alessandro Perutelli, 'Pluralità di modelli e discontinuità narrative: l'episodio della morte di Esone in Valerio Flacco (1, $747 \mathrm{sgg}.)^{\prime}$, MD 7 (1982), 129, sees both literary (Creusa) and historical (Seneca's wife) models as appropriate to Alcimede: 'I modelli che vengono qua a sovrapporsi, malgrado la loro diversa natura, non scatenano contraddizioni perché entrambi, la consorte troiana $\mathrm{e}$ quella più attuale del perseguitato romano, caratterizzati da tratti eroici, che ben corrispondono alle più opportune raffigurazione di Alcimede.'

36. P.R. Taylor, 'Valerius' Flavian Argonautica', CQ 44 (1994), 212-35.

37. Arria Maior's leading by example is a different kind of female suicide than that of the wife following her husband and thus I will not treat it here as it is not represented in the literary sources and, in fact, may be sui generis.

38. Nero iubet inhiberi mortem ('Nero orders death to be prevented', Tac. Ann. 15.64).

39. Tac. Ann. 3.13.

40. Lucan $B C 8.651-62$.

41. Likewise, Pelias' threat is against a single parent: sunt hic etiam tua uulnera, praedo,/sunt lacrimae carusque parens ("these then are your wounds, you brigand, and your tears-your dear parent', Arg. 1.723f.).

42. Arg. 1.741-46.

43. McGuire (n.24 above 'Textual Strategies'), $27 \mathrm{f}$.

44. McGuire (n.24 above 'Textual Strategies'), 28.

45. Livy $A U C 21.14$.

46. Polybius 3.17 .

47. McGuire (n.24 above 'Textual Strategies'), 37-39.

48. Lucan $B C$ 2.148-59.

49. Text and translation (somewhat modified): B. Perrin (ed. and tr.), Plutarch Lives IX: Demetrius and Antony, Pyrrhus and Gaius Marius (London and Cambridge MA 1920), 536f.

50. Text and translation: H.St.J. Thackeray (ed. and tr.), Josephus III: The Jewish War Books IV-VII (London and Cambridge MA 1928), $616 f$. 


\section{JESSICA DIETRICH}

51. William Dominik, 'Hannibal at the Gates: Programmatising Rome and Romanitas in Silius Italicus' Punica 1 and 2', in Boyle and Dominik (n.29 above), 490.

52. Cf. Dominik (n.51 above), 488. David Vessey, 'Silius Italicus on the Fall of Saguntum', $C P$ 69 (1974), 28-36, views the two appearances of Tiburna as a framing device for the episode.

53. Like Tisiphone in Punica 2, Iris assumes the likeness of a mortal woman, in this case Beroe (Aen . 5.617-20). Just as Iris/Beroe enters the crowd of women so Tisiphone/Tiburna breaks into the midst of the gathered citizens: mediam se matribus refert (Aen. 5.622) and medios irrumpit (Pun. 2.559). Cf. Spaltenstein (n.2 above), 163.

54. Aen. 5.636-38.

55. Pun. 2.575-77.

56. ignea sanguinea radiabant lumina flamma ('its flaming eyes were shining with blood-red fire', Pun. 2.586).

57. This is what she claimed after her arrest. Other valid interpretations are that she decided not to follow her husband or that she never intended to.

58. Robert Pape, 'The Suicide Bomber', News Hour with Jim Lehrer, November 14, 2005, accessed at: http://www.pbs.org/newshour/bb/terrorism/july-dec05/bombers_11-14.html.

59. Debra Zedalis, Female Suicide Bombers (Carlisle PA 2004), accessed at: http://www au.af. mil/au/awc/awcgate/ssi/zedalis.pdf, 7 .

60. Zedalis (n.59 above), 7.

61. Zedalis (n.59 above), 8 . 